\title{
ІНТЕНСИФІКАЦІЯ ОЧИЩЕННЯ ДРЕНАЖНИХ ВОД ПОЛІГОНІВ ТВЕРДИХ ПОБУТОВИХ ВІДХОДІВ
}

\author{
Дегтяр М. В.
}

\section{ВСТУП}

Основним фактором негативного впливу полігона твердих побутових відходів (далі - ТПВ) на навколишнє середовище $є$ вплив фільтраційних вод, що утворюються в результаті розкладання відходів. Забезпечення стабільно сприятливого санітарного стану території та охорони водного, повітряного басейнів вимагає розроблення та впровадження високоефективних технологій очищення фільтраційних вод полігонів ТПВ ${ }^{1}$.

Одним із найпоширеніших способів знешкодження ТПВ $\epsilon$ їх депонування на полігонах, де протягом десятків років протікають процеси розкладання відходів. Останнє призводить до локальних або глобальних змін санітарно-епідеміологічної ситуації прилеглих територій.

Для захисту грунтових і поверхневих вод від забруднення під час будівництва полігонів передбачаються такі заходи:

- відкачка фільтрату з тіла полігона 3 подальшим видаленням на очисні споруди;

- створення багатошарового екрана по дну та укосах котловану, в якому розміщається полігон ТПВ.

Склад фільтрату прямо залежить від етапу життєвого циклу полігона. Кожному етапу відповідає певна стадія біохімічного розкладання відходів, яка лежить в основі формування кількісних i якісних характеристик дренажних вод.

Для очищення висококонцентрованих дренажних вод полігонів ТПВ використовуються фізичні, хімічні, біологічні методи, а також їх комбінація. У даній роботі пропонується використання комбінації вищезгаданих методів із застосуванням розчину коагулянту сульфату алюмінію, підданого активації шляхом магнітної обробки та електрокоагуляції ${ }^{2}$.

\footnotetext{
${ }^{1}$ Кашковський В.І., Кухар В.П. Способи знешкодження високотоксичних стоків звалищ твердих побутових відходів. Наука та інноваиії. 2005. № 6, Т. 1. С. 107-116.

2 Ресурсосберегающие технологии очистки сточных вод: монография / С.С. Душкин и др.; Харьк. нац. акад. городского хоз-ва. Х. : ХНАГХ, 2011. 168 с.
} 
Дана технологія дозволить інтенсифікувати процес очищення дренажних вод, знизити дози сульфату алюмінію без погіршення якості очищення стічних вод, знизити експлуатаційні витрати та собівартість очищення дренажних вод.

Доцільність застосування активованого розчину коагулянту в процесі очищення дренажних вод із технологічної та економічної точки зору обгрунтована дослідженнями, виконаними в лабораторних умовах i на пілотній установці на очисних спорудах дренажних вод на полігоні ТПВ.

\section{1. Аналіз методів. Граничні умови їх використання}

У результаті протікання в тілі полігона процесів анаеробного розкладання ТПВ, проникнення всередину тіла полігона атмосферних опадів утворюється фільтрат, який містить продукти вилужування водорозчинних сполук і продукти розкладання відходів. На більшості полігонів і смітників України фільтрат із тіла полігона не очищається та стікає в найближчі водотоки, а скидання фільтрату у водойми загального користування категорично неприпустимо.

Відомо, що хімічний склад фільтрату прямо залежить від морфологічного складу ТПВ, що у свою чергу безпосередньо впливає на вибір методу й способу очищення. Очищення дренажних вод являє собою надзвичайно складну проблему та вимагає комбінації різних фізико-хімічних i біологічних методів, значних капітальних і експлуатаційних витрат.

Технологічні схеми очищення фільтрату грунтуються на застосуванні переважно методів біохімічної деструкції органічних речовин у комбінації з фізико-хімічними процесами - коагуляціїфлотації, фільтрації, ультрафільтрації, адсорбції, зворотного осмосу, концентрованого випарювання в різних комбінаціях ${ }^{3}$.

Фільтрат 3 органічними домішками зазвичай очищують за допомогою біохімічних методів, а також залежно від концентрацій присутніх компонентів застосовують аеробне або анаеробне очищення. Для доочищення використовують адсорбційні методи (завантаженням виступає активне вугілля та інші сорбенти) ${ }^{4}$.

Анаеробні методи більш ефективні для стадії ацетогенезу полігона, що характерно для експлуатаційного циклу експлуатації полігону ТПВ. Основними перевагами анаеробної очистки в порівнянні з аеробною можуть бути виділені такі ${ }^{5}$ :

${ }^{3}$ Baig S. Treatment of landfill leachates : Lapeyrouse and Satrod case studies. Ozone science and engineering. 21. 1999. P. 1-22.

${ }^{4}$ Safaa. M. Raghab, Ahmed M Abd EI Meguid, Hala A Hegazi. Treatment of leachate from municipal solid waste landfill. HBRC Journal. 2013. № 9, P. 187-192.

${ }^{5}$ Welander U., Henrysson T. Nitrification of landfill Leachate Using SuspendedCarrier Biofilm Technology. Water Research. 1997. № 31(9). P. 2351-2355. 
- не потрібна подача кисню в оброблюване середовище;

- значно зменшуються витрати електроенергії;

- збільшується мінералізація анаеробного осаду під час видалення важких металів, що підвищує цінність його як добрива;

- знижується кількість добавок для живлення мікрофлори;

До недоліків анаеробного очищення можна віднести такі:

- необхідність високих (більш $30^{\circ} \mathrm{C}$ ) температур для досягнення ефективної кінетики процесу;

- менша ефективність видалення важких металів.

Застосування аеробних методів для очищення фільтрату в стадії метаногенезу можливе за проведення попереднього фізико-хімічного та хімічного очищення, тому що стоки мають високий солевміст, наявність хлорорганічних сполук.

Таким чином, у разі використання біохімічного очищення на стадії метаногенезу рекомендується попередня хімічна або фізико-хімічна обробка;

- використання сорбційного очищення на стадії метаногенезу рекомендується для низькоконцентрованих фільтраційних вод;

- за використання гальванокоагуляції та реагентної коагуляції на стадії ацетогенезу досягається зниження БПК до 60\%, кольоровості до $85 \%$;

- за використання мембранних технологій очищення на стадіях ацето- і метаногенезу без передочищення відбувається швидке засмічення мембран та утворення концентрату, складного в подальшій утилізації, метод через складність в експлуатації та відносну дорожнечу не може бути рекомендований як основний, але може бути використаний як доочищення на будь-якому етапі життедіяльності полігона ТПВ.

Специфіка складу стічних вод полігонів ТПВ зумовила необхідність застосування комплексних технологій очищення, тому що найчастіше використання одного методу або способу не дозволяе досягти необхідних результатів.

\section{2. Дослідження ефективності запропонованої технології}

Таким чином, метою проведених досліджень $є$ теоретичне й дослідно-промислове обгрунтування використання активованого розчину коагулянту сульфату алюмінію, який зазнає магнітноелектричної активації, що дозволяє інтенсифікувати процес очищення дренажних стічних вод полігонів ТПВ, знизити витрати реагентів у середньому на 25-30\% без погіршення якості очищення води.

Дослідження 3 ефективності застосування технології очищення дренажних вод полігонів ТПВ проводилися як у лабораторних умовах, так і на пілотній установці. 
Закономірності очищення стічної води за використання активованого розчину реагенту були досліджені на модельній воді та дренажних водах, що утворюються на полігоні ТПВ різних міст України, в тому числі Києва та Запоріжжя.

Якісна характеристика дренажних стічних вод наведена в табл. 1.

Таблиця 1

Якісна характеристика дренажних вод полігона ТПВ

\begin{tabular}{|c|c|c|c|c|}
\hline \multirow{2}{*}{$\begin{array}{c}\text { Найменування } \\
\text { показника }\end{array}$} & \multicolumn{3}{|c|}{ Період досліджень } & \multirow{2}{*}{ Примітка } \\
\hline & Зимовий & Весняний & Осінній & \\
\hline $\begin{array}{l}\text { Сухий залишок, } \\
\text { мг/дм }\end{array}$ & 18352,7 & 23200,5 & 22614,3 & \multirow{9}{*}{ 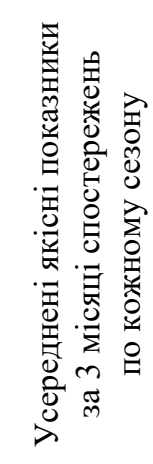 } \\
\hline БПК ${ }_{5}, \mathrm{мгО} /$ дм $^{3}$ & 167,7 & 165,3 & 182,1 & \\
\hline ХПК, мг/дм ${ }^{3}$ & 1215,6 & 999,8 & 1007,5 & \\
\hline Кольоровість, гради. & 167 & 159 & 180 & \\
\hline $\begin{array}{l}\text { Завислі речовини, } \\
\text { мг/дм }\end{array}$ & 268,07 & 209,7 & 251,4 & \\
\hline $\mathrm{pH}$ & 7,1 & 7,4 & 7,6 & \\
\hline Азот, мг/дм ${ }^{3}$ & 262,3 & 76,24 & 67,7 & \\
\hline Нітрати, мг/дм $^{3}$ & 120,2 & 107,8 & 109,4 & \\
\hline Сульфати, мг/дм ${ }^{3}$ & 2154,8 & 2376,8 & 1630,1 & \\
\hline
\end{tabular}

Експеримент виконувався паралельно для умов звичайної коагуляції і для стічної води, обробленої активованим розчином коагулянту сульфату алюмінію.

На першому етапі експерименту в змішувач додається звичайний розчин сульфату алюмінію, на другому етапі подають наступну порцію стічної води 3 додаванням у змішувач активованого розчину коагулянту.

Для активації розчинів реагентів використовується спеціальний пристрій, що передбачає одночасну та послідовну активацію розчину магнітним полем і насичення його анодно-розчиненим залізом ${ }^{6}$.

Механізм впливу активованих розчинів реагентів на процеси очищення води можна пояснити такими факторами: накладення на водні розчини зовнішнього магнітного поля змінює їхню структуру та створює умови для утворення іонних асоціатів субмікроскопічного та колоїдного ступеня

${ }^{6}$ Пат. № 45190 Україна, МПК ${ }^{51}$ (2009) CO2F 1/48 Спосіб очищення стічних вод полігонів твердих побутових відходів / Душкін С.С., Корінько І.В., Солодовник М.В., Ткачов В.О.; заявник та правовласник ХНАМГ. № 45190; заявл. 09.06.2009 р.; опубл. 26.10.2009 р., Бюл. № 20. 
дисперсності; асоціати, що виникли під впливом магнітного поля, є зародками нової фази субмікроскопічного та колоїдного ступеня дисперсності та після їх стабілізації виконують роль додаткових центрів коагуляції; стабілізація іонних асоціатів здійснюється за допомогою анодно-розчиненого заліза, вміст якого не перевищує 1000-1500 мг/дм ${ }^{3}$ $10 \%$ розчину коагулянту сульфату алюмінію ${ }^{7}$.

Активування розчину коагулянту здійснюється в спеціальному пристрої, що передбачає утворення іонних асоціатів, що виникають унаслідок магнітної обробки та закріплення ї анодно-розчиненим залізом.

Схема ланцюга апаратів для активування розчинів коагулянту наведена на рисунку 1.

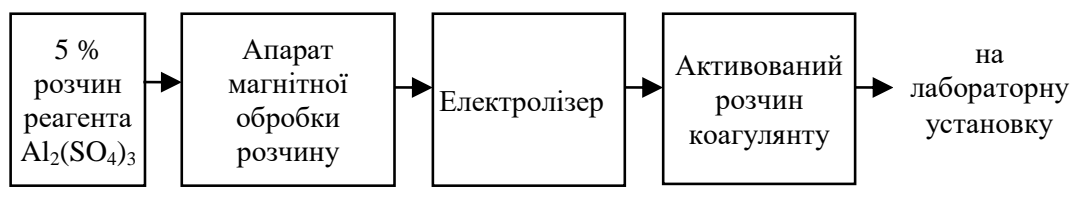

Рис. 1. Схема ланцюга апаратів для активування розчинів коагулянту

Пристрій складається із двох послідовно з'єднаних апаратів: магнітного активатора та електрокоагулятора. Розчин реагенту, проходячи в робочому зазорі між корпусом магнітопроводу та полюсним наконечником, зазнає впливу магнітного поля, що створюється електромагнітною котушкою. Далі розчин надходить в електрокоагулятор, де насичується анодно-розчиненим залізом.

У процесі дослідження визначалися такі показники очищених стічних вод:

- вміст завислих речовин;

- кольоровість;

- БПК

- ХПК;

- залишковий вміст алюмінію.

Кількість залишкового алюмінію в очищеній стічній воді має велике значення під час здійснення біологічного очищення, зокрема може викликати пригнічення активності активного мулу на спорудах біологічного очищення.

${ }^{7}$ Дегтяр М.В. Інтенсифікація процесів очищення висококонцентрованих стічних вод. Вісник Начіонального університету водного господарства та природокористування: зб. наукових праць. Вип.1 (69). Рівне: НУВГП, 2015. C. 111-116. 
Був вибраний такий технологічний регламент роботи пілотної установки:

- продуктивність пілотної установки - 432 л/год (18 л/година);

- параметри активації;

- напруженість магнітного поля - 325 кА/м;

- вміст анодно-розчиненого заліза в розчині коагулянту 112,5 мг/дм ${ }^{3}$;

- доза коагулянту -210 мг/дм³.

Для ефективного біологічного очищення пропонується використання заглибних біодискових фільтрів, що представляють собою резервуари із днищем увігнутої форми (ванни), заповнені стічною водою. Уздовж резервуара, на 20 мм вище рівня оброблюваної стічної рідини встановлений вал, на який насаджені пластмасові диски діаметром 300 мм. Відстань між дисками становить 10 мм, частота обертання вала 3 дисками - 1-10 об/хв.

Під час роботи в заглибному біофільтрі не відбувається відкладення осаду, а товщина біоплівки залежить від надходження живильних речовин і споживання кисню.

Характеристика біодискових фільтрів, прийнятих під час виконання досліджень:

- кількість біодисків - 8;

- матеріал біодисків - пластмаса (з перфорацією);

- діаметр біодисків - 300 мм;

- відстань між дисками -10 мм;

- товщина дисків - 2 мм;

- частота обертання вала -4 об/хв;

- розмір ванни - 1150 х 350 мм;

- час перебування - 60 хвилин;

- висота вала над рівнем стічної води - 20 мм.

Дренажні води надходять у збірник для забезпечення рівномірної та безперебійної подачі фільтрату. Активатор реагентів установлений на обвідній лінії та використовується згідно з регламентом дослідження. У змішувачі відбувається змішування розчину коагулянту (активованого або звичайного - згідно з регламентом) зі стічними водами, далі самопливом по трубопроводу стічна вода направлясться в блок споруд, який являє собою первинний відстійник, ванну із заглибними біодисками та секцію вторинного відстійника. Далі потік направляється на біодиски, 
занурені у ванну зі стічною водою. Наступна секція виконує роль вторинного відстійника. Осад та мул, що утворюються у вторинному та первинному відстійниках, періодично видаляються. Блок споруд застосовується для скорочення площі, прискорення та інтенсифікації процесів відстоювання та біологічного очищення. Після вторинного відстійника для знезараження встановлений блок бактерицидних ламп. Далі для доочистки вода самопливом направляється на фільтр, завантажений кварцовим піском. Скидання знешкодженого стоку може здійснюватися у промислову каналізацію.

Результати виконаних досліджень представлені в табл. 2.

Аналіз отриманих даних показує, що використання активованого розчину коагулянту сульфату алюмінію дозволяе підвищити якість очищення дренажних вод за вмістом завислих речовин і кольоровістю (40\% і 43\% відповідно), трохи нижче ефективність очистки дренажних вод за використання активованого розчину коагулянту хлориду заліза $23 \%$ і $37 \%$ відповідно.

Під час оброблення дренажних вод активованим розчином коагулянту сульфату алюмінію ефективність очищення зростає в середньому на $30-40 \%$, а за використання активованого розчину хлориду заліза - на 20-30\%.

Залишковий вміст алюмінію за використання розчину коагулянту сульфату алюмінію перебуває в межах 0,15-0,20 мг/дм ${ }^{3}$ та не має негативного впливу на мікроорганізми активного мулу під час біологічної обробки; залишковий вміст заліза за використання коагулянту хлориду заліза перебуває в межах 1,3-1,5 мг/дм³ ${ }^{3}$ що також не перевищує припустимих концентрацій під час біологічного очищення.

Отже, використання активованих розчинів коагулянтів дозволяє підвищити ефективність очищення по всіх контрольованих показниках.

Найбільш відчутний ефект був зафіксований у разі дози коагулянту 210 мг/дм ${ }^{3}$, за якої вміст завислих речовин становив 58,3 мг/дм ${ }^{3}$ під час обробки звичайним розчином коагулянту та 39,7 мг/дм ${ }^{3}$ під час обробки активованим розчином коагулянту, кольоровість становила 99 і 61 град. відповідно. Отримані виводи підтверджуються даними діаграми, наведеної на рисунку 2.

Проаналізувавши показники ефективності очищення за використання звичайного розчину коагулянту (вміст завислих речовин

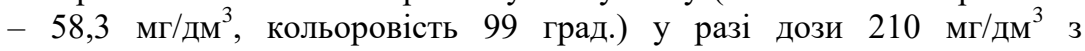
показниками ефективності очистки за використання активованого розчину коагулянту (вміст завислих речовин - 62,3 мг/дм ${ }^{3}$, кольоровість 92 град.) у разі дози 150 мг/дм³ ${ }^{3}$ можна зробити висновок, що використання активованого розчину коагулянту дозволяе здобути зниження розрахункових доз коагулянту без зміни якості фільтрату. 


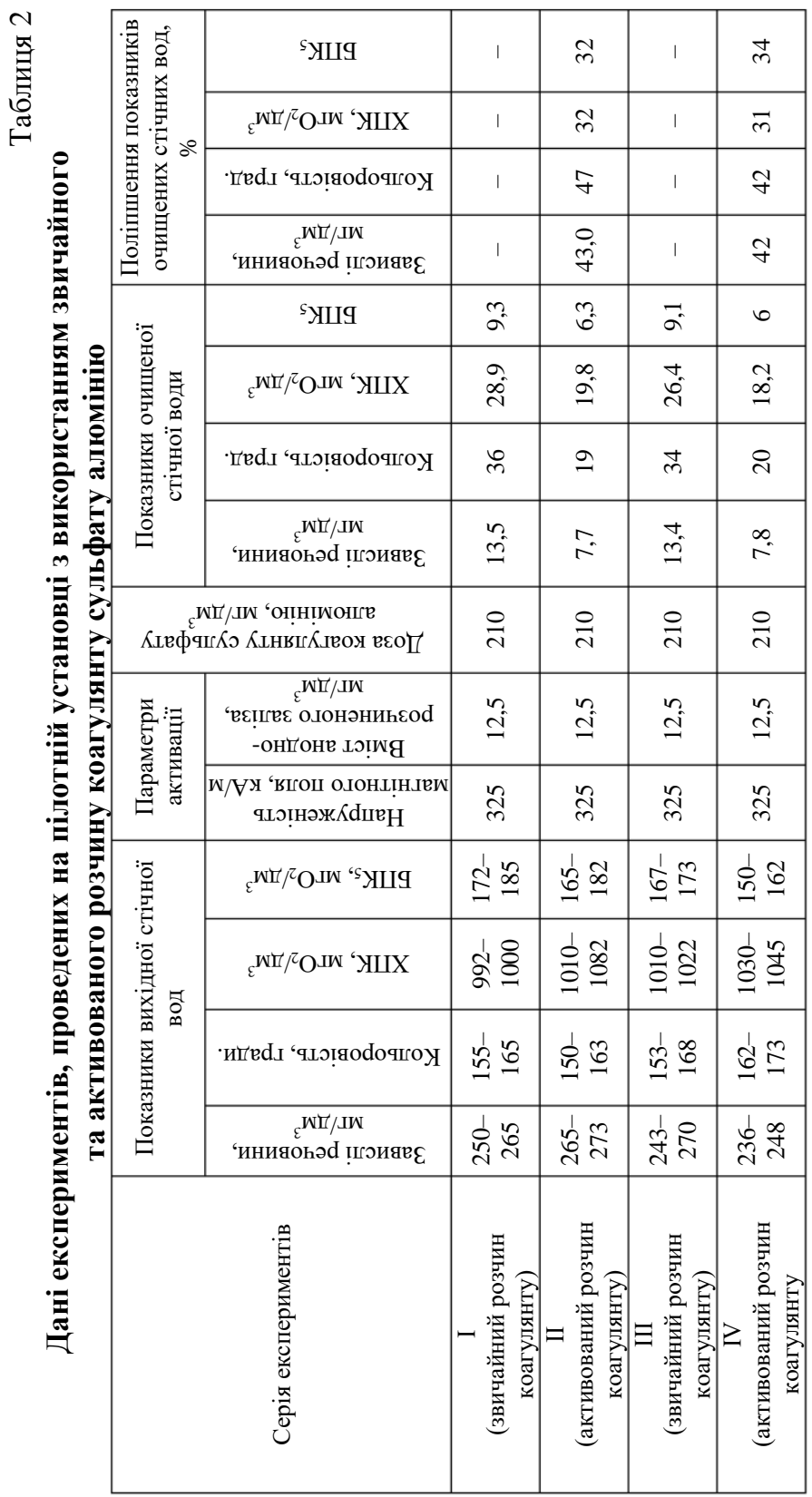




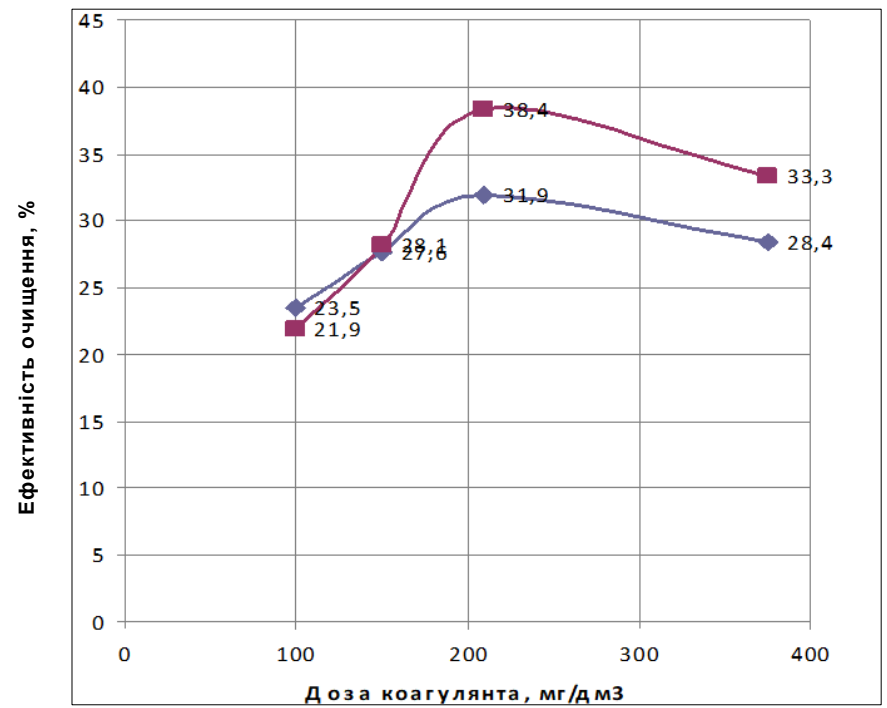

Покращення якості очищення за вмістом завислих речовин

Покращення якості очищення за кольоровістю

Рис. 2. Поліпшення якості очищення стічних вод у разі використання активованого розчину коагулянту

Отже, застосування активованого розчину коагулянту сульфату алюмінію дозволяє знизити розрахункову дозу коагулянту, в порівнянні зі звичайним розчином коагулянту, в середньому на $29 \%$, при цьому якість фільтрату не погіршується.

Інтенсифікацію процесів очищення стічних вод полігонів ТПВ у разі використання активованого розчину сульфату алюмінію можна пояснити такими факторами: порушенням динамічної рівноваги воднодисперсної системи, що створює умови для утворення іонних асоціатів - зародків нової фази, що виконують роль додаткових центрів коагуляції i, як наслідок, зниження ступеня структурно-механічної гідратації суспензії; збільшенням питомої ваги коагуляційних структур.

Установлено, що в разі використання активованого розчину коагулянту середня швидкість ущільнення контактного середовища вища, ніж у разі застосування звичайного розчину коагулянту, відбувається зміцнення пластівців завислого осаду, поліпшення його осаджуваності, що дозволить збільшити сили зчеплення часток контактного середовища в середньому на 15-30\%, інтенсифікувати процеси очищення стічних вод на біодискових фільтрах і підвищити ефект від реагентного очищення. 
Для оптимізації процесу очищення використовується моделювання. Оптимізації технологічного процесу очищення дренажних вод можна досягти за допомогою математичних моделей т. б. залежності ефекту очищення від вихідних якісних характеристик і параметрів активації розчинів коагулянту (у даному випадку сульфату алюмінію).

Для розв'язання поставленого завдання був вибраний математичний метод обробки експериментальних даних ${ }^{8}$, що дає можливість одержати найбільш достовірні емпіричні залежності за порівняно невеликої кількості дослідів.

Для ефективного аналізу механізму очищення стічних вод полігонів ТПВ необхідно виявити взаємозв'язок факторів, що визначають хід процесу, й представити їх у кількісній формі - у вигляді математичної моделі, яка буде відображенням найбільш істотних сторін процесу очищення. Вона являє собою сукупність співвідношень, що визначають характеристики станів об'єкта досліджень залежно від параметрів об'єкта та умов.

Прогнозування значень факторів впливу - найбільш важливий аспект процесів очищення стічних вод полігонів ТПВ, що дозволяє вибудовувати роботу блоків очищення 3 урахуванням параметрів вихідної води.

\section{3. Прогнозування якості очищення. Економічна оцінка методу}

Прогнозування здійснюється на основі експериментальних даних, для одержання більш точних даних експеримент проводиться 3 урахуванням сезонного коливання якісних показників дренажних вод полігонів ТПВ.

Під час розроблення моделі для прогнозування ефективності по БПК 5 дренажних стічних вод полігонів ТПВ основними факторами були прийняті:

- показник БПК 5 , вихідної води, мгО/дм ${ }^{3}-\mathrm{P}$;

- доза коагулянту, мг/дм ${ }^{3}-\mathrm{D}$;

- швидкість фільтрування на фільтрах, м/год - V.

Для моделювання використовуємо повний факторний експеримент, т. б. експеримент, в якому реалізуються різні комбінації рівнів факторів. За допомогою варіювання факторів впливу на двох рівнях були сформульовані матриці планування під час використання біодисків і активованого розчину сульфату алюмінію під час очищення стічних вод даної категорії.

Умови планування експерименту наведені в табл. 3.

8 Джонсон Н., Лион Ф. Статистика и планирование эксперимента в технике и науке. М.: Мир, 1988. 520 с. 
Таблиця 3

Умови планування експерименту

\begin{tabular}{|c|c|c|c|c|c|}
\hline \multicolumn{2}{|l|}{ Фактори } & \multicolumn{3}{|c|}{ Рівні варіювання } & \multirow{2}{*}{$\begin{array}{c}\text { Інтервал } \\
\text { варіювання }\end{array}$} \\
\hline Найменування & $\begin{array}{l}\text { Кодовий } \\
\text { вид }\end{array}$ & -1 & 0 & +1 & \\
\hline \multicolumn{6}{|c|}{ Коагулянт - сульфат алюмінію } \\
\hline БПК & $\mathrm{X}_{1}$ & 200 & 230 & 260 & 30 \\
\hline Доза коагулянту, мг/дм³ ; & $\mathrm{X}_{2}$ & 100 & 150 & 200 & 50 \\
\hline $\begin{array}{l}\text { Швидкість фільтрування } \\
\text { на фільтрі, м/год }\end{array}$ & $\mathrm{X}_{3}$ & 8 & 10 & 12 & 2,0 \\
\hline
\end{tabular}

Матриця планування експерименту й результати експериментів наведені в табл. 4.

Таблиця 4

Матриця планування експерименту та результати експериментів

\begin{tabular}{|c|c|c|c|c|c|c|c|c|c|}
\hline \multirow{2}{*}{$\begin{array}{l}\text { Номер } \\
\text { досліду }\end{array}$} & \multicolumn{4}{|c|}{$\begin{array}{c}\text { Матриця } \\
\text { планування }\end{array}$} & \multicolumn{3}{|c|}{$\begin{array}{c}\text { Паралельні } \\
\text { досліди }\end{array}$} & \multirow{2}{*}{$\begin{array}{c}\text { Середнє } \\
\text { значення } \\
\text { параметра, } \\
\bar{E}_{\text {зн }}, \% \\
\end{array}$} & \multirow{2}{*}{$\begin{array}{c}\text { Оцінка } \\
\text { дисперсії, } \\
S_{j}^{2}\end{array}$} \\
\hline & $\mathrm{X}_{0}$ & $X_{1}$ & $X_{2}$ & $X_{3}$ & 1 & 2 & 3 & & \\
\hline 1 & +1 & +1 & -1 & +1 & 78,2 & 78,8 & 79,1 & 78,7 & 0,21 \\
\hline 2 & +1 & -1 & +1 & +1 & 79,8 & 80,3 & 80,5 & 80,2 & 0,13 \\
\hline 3 & +1 & +1 & -1 & -1 & 77 & 81 & 82 & 80 & 7 \\
\hline 4 & +1 & -1 & -1 & -1 & 77,6 & 77,7 & 78,1 & 77,8 & 0,07 \\
\hline 5 & +1 & +1 & +1 & +1 & 76,3 & 76,7 & 76,8 & 76,6 & 0,07 \\
\hline \multicolumn{10}{|c|}{ Коагулянт - сульфат алюмінію } \\
\hline 6 & +1 & -1 & +1 & -1 & 80 & 81,2 & 82,7 & 81,3 & 1,83 \\
\hline 7 & +1 & +1 & +1 & -1 & 78,5 & 80,1 & 82,9 & 80,5 & 4,96 \\
\hline 8 & +1 & -1 & -1 & +1 & 75,2 & 77,9 & 79,4 & 77,5 & 4,53 \\
\hline$\sum$ & & 18,8 & & & & & & & \\
\hline
\end{tabular}

Ефективність очищення дренажних вод полігонів ТПВ по показнику БПК 5 наведена в табл. 5. 
Таблиця 5

Ефективність очищення дренажних вод полігонів ТПВ по показнику БПК

\begin{tabular}{|c|c|c|c|c|c|}
\hline $\begin{array}{c}\text { № серії } \\
\text { експери- } \\
\text { менту }\end{array}$ & $\begin{array}{c}\text { Кількість } \\
\text { паралельн } \\
\text { их дослідів }\end{array}$ & $\begin{array}{c}\text { Вихідний } \\
\text { показник } \\
\text { БПК }_{5}\end{array}$ & $\begin{array}{c}\text { Показник } \\
\text { БПК після } \\
\text { очищення, } \\
\text { мГО/дм }{ }^{3}\end{array}$ & $\begin{array}{c}\text { Ефект } \\
\text { очищення, } \\
\%\end{array}$ & $\begin{array}{c}\text { Усеред- } \\
\text { нене } \\
\text { значення } \\
\text { ефектив- } \\
\text { ності, \% }\end{array}$ \\
\hline \multirow{3}{*}{1} & 1 & \multirow{3}{*}{220} & 47,96 & 78,2 & \multirow{3}{*}{78,7} \\
\hline & 2 & & 46,64 & 78,8 & \\
\hline & 3 & & 45,98 & 79,1 & \\
\hline \multirow{3}{*}{2} & 1 & \multirow{3}{*}{235} & 47,47 & 79,8 & \multirow{3}{*}{80,2} \\
\hline & 2 & & 46,29 & 80,3 & \\
\hline & 3 & & 45,825 & 80,5 & \\
\hline \multirow{3}{*}{3} & 1 & \multirow{3}{*}{260} & 59,8 & 77 & \multirow{3}{*}{80,0} \\
\hline & 2 & & 49,4 & 81 & \\
\hline & 3 & & 46,8 & 82 & \\
\hline \multirow{3}{*}{4} & 1 & \multirow{3}{*}{210} & 47,04 & 77,6 & \multirow{3}{*}{77,8} \\
\hline & 2 & & 46,83 & 77,7 & \\
\hline & 3 & & 45,99 & 78,1 & \\
\hline \multirow{3}{*}{5} & 1 & \multirow{3}{*}{200} & 47,4 & 76,3 & \multirow{3}{*}{76,6} \\
\hline & 2 & & 46,6 & 76,7 & \\
\hline & 3 & & 46,4 & 76,8 & \\
\hline \multirow{3}{*}{6} & 1 & \multirow{2}{*}{250} & 50 & 80 & \multirow{2}{*}{81,3} \\
\hline & 2 & & 47 & 81,2 & \\
\hline & 3 & & 43,25 & 82,7 & \\
\hline \multirow{3}{*}{7} & 1 & \multirow{3}{*}{240} & 51,6 & 78,5 & \multirow{3}{*}{80,5} \\
\hline & 2 & & 47,76 & 80,1 & \\
\hline & 3 & & 41,04 & 82,9 & \\
\hline \multirow{3}{*}{8} & 1 & \multirow{3}{*}{207} & 51,34 & 75,2 & \multirow{3}{*}{77,5} \\
\hline & 2 & & 45,747 & 77,9 & \\
\hline & 3 & & 42,642 & 79,4 & \\
\hline
\end{tabular}

У результаті проведених досліджень отримана функціональна залежність, яка вірогідно описує досліджуваний процес очищення дренажних стічних вод у разі застосування біодисків і активованого розчину коагулянту сульфату алюмінію: 


$$
Э=79,07-0,825 \cdot D-0,975 \cdot P \cdot V
$$

Порівняння експериментальних і розрахункових даних у визначенні ефективності зниження БПК 5 під час очищення стічних вод на біодисках із застосуванням активованого розчину коагулянту сульфату алюмінію наведено на рисунку 3 .

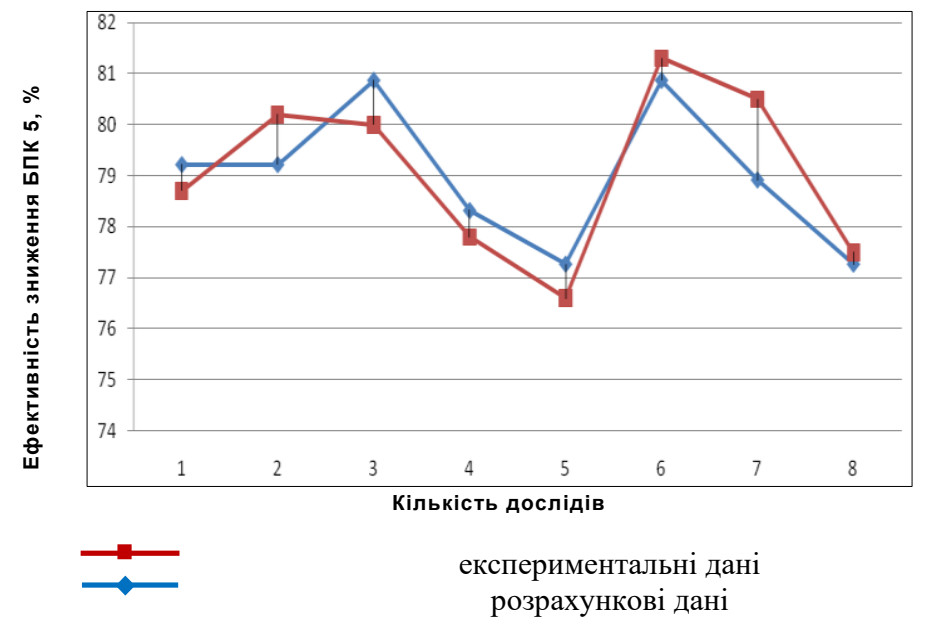

Рис. 3. Порівняння експериментальних і розрахункових даних у визначенні ефективності зниження БПК 5 у разі застосування активованого розчину сульфату алюмінію

Таким чином, математична залежність ефективності зниження БПК дренажних вод від різних факторів у разі використання активованого розчину сульфату алюмінію досить повно описує досліджуваний процес, що дозволяє зробити висновок про можливість застосування математичної залежності для обгрунтування технологічного регламенту під час очищення фільтраційних стічних вод полігонів ТПВ за допомогою активованого розчину коагулянту сульфату алюмінію та біодисків.

Для оцінки ефективності впровадження технології очищення дренажних стічних вод 3 використанням активованого розчину сульфату алюмінію на стадії передочищення визначали економічний ефект від впровадження розробленої технології за результатами дослідно-промислових випробувань пілотної установки на полігоні;

Розрахунки економічної ефективності від впровадження активованого розчину сульфату алюмінію за результатами досліднопромислових випробувань пілотної установки виконані на підставі вихідних даних, наведених у таблиці 6. 
Згідно з дослідженнями, наведеними вище, зниження розрахункової дози коагулянту сульфату алюмінію за його активації буде становити в середньому $25 \%$.

Таблиця 6

Вихідні дані для розрахунків економічного ефекту

\begin{tabular}{|c|c|c|c|c|c|}
\hline $\begin{array}{l}\text { № } \\
\text { п/п }\end{array}$ & Вид показника & $\begin{array}{l}\text { Умов. } \\
\text { познач }\end{array}$ & $\begin{array}{l}\text { Од. } \\
\text { вимір. }\end{array}$ & $\begin{array}{l}\text { Базовий } \\
\text { варіант }\end{array}$ & $\begin{array}{l}\text { Впрова- } \\
\text { джений } \\
\text { варіант }\end{array}$ \\
\hline 1 & $\begin{array}{l}\text { Продуктивність очисних } \\
\text { споруд }\end{array}$ & Q & м³/доб & 300 & 300 \\
\hline 2 & $\begin{array}{l}\text { Середня доза коагулянту } \\
\mathrm{Al}_{2}\left(\mathrm{SO}_{4}\right)_{3}\end{array}$ & $Д_{\kappa}$ & $\Gamma / M^{3}$ & 250 & 200 \\
\hline 3 & $\begin{array}{l}\text { Річна витрата коагулянту } \\
\mathrm{Al}_{2}\left(\mathrm{SO}_{4}\right)_{3}\end{array}$ & $\mathrm{P}_{\mathrm{K}}$ & $\mathrm{T}$ & 27,4 & 21,9 \\
\hline 4 & $\begin{array}{l}\text { Вартість коагулянту } \\
\mathrm{Al}_{2}\left(\mathrm{SO}_{4}\right)_{3}\end{array}$ & $\mathrm{C}_{\mathrm{K}}$ & грн/т & 10000 & 10000 \\
\hline 5 & Вартість електроенергії & $\mathrm{C}_{\mathrm{e}}$ & $\begin{array}{c}\text { грн/ } \\
\text { кВт·год }\end{array}$ & 0,618 & 0,618 \\
\hline 6 & $\begin{array}{l}\text { Вартість активатора } \\
\text { реагентів }\end{array}$ & Ц & грн. & - & 6300 \\
\hline 7 & $\begin{array}{l}\text { Потужність активатора } \\
\text { реагентів }\end{array}$ & $\mathrm{N}$ & КВт·год & - & 0,5 \\
\hline
\end{tabular}

Технологічна схема очищення дренажних вод полігона ТПВ за базовим варіантом включає: реагентне господарство, змішувач, первинний i вторинний відстійник, заглибні біодискові фільтри, бактерицидну лампу та каркасно-засипний фільтр.

Витрати на виготовлення та монтаж активатора реагентів прийняті рівними витратам на будівництво та реконструкцію реагентного господарства за базовим варіантом.

Згідно $з$ даними таблиці 6 і технологічними розрахунками (базовий варіант) для очищення заданого обсягу стічних вод $\left(300 \mathrm{~m}^{3} /\right.$ доб) необхідно $0,08 \mathrm{~m}^{3} 10 \%$-го звичайного та $0,06 \mathrm{~m}^{3}$ активованого розчину коагулянту сульфату алюмінію (з урахуванням зниження дози на 25\%). 3 урахуванням необхідного обсягу продуктивність активатора становить $0,01 \mathrm{~m}^{3} /$ год за тривалості роботи активатора реагентів 6 годин на добу.

Розрахунок річного економічного ефекту від впровадження активованого розчину коагулянту для очищення дренажних вод полігонів ТПВ виконувався за формулою: 


$$
E=C_{\kappa}^{\prime}-C_{\kappa}^{\prime \prime}-C_{\ni}
$$

де $C_{\kappa}^{\prime}$ - витрати на придбання коагулянту сульфату алюмінію за базовим варіантом, грн; $C_{\kappa}^{\prime \prime}-$ витрати на придбання коагулянту сульфату алюмінію за впровадженим варіантом, грн; $C_{\text {э }}$ - витрати на електроенергію, грн

$$
C_{\kappa}^{\prime}=10000 \cdot 27,4=274000 \text { грн. }
$$

Витрати на придбання коагулянту за впровадженим варіантом:

$$
C_{\kappa}^{\prime}=10000 \cdot 21,9=219000 \text { грн }
$$

Витрати на електроенергію становитимуть:

$$
C_{\ni}=C_{\ni} \cdot N_{\ni},
$$

де $c_{э}-$ вартість 1 кВт.ч електроенергії, грн; $N_{э}-$ витрата електроенергії для живлення активатора реагентів.

$$
N_{\ni}=N \cdot t \cdot 365 \text {, }
$$

де $N$ - потужність активатора реагентів, кВт·год; $t$ - час роботи активатора реагентів протягом доби, год.

$$
\begin{gathered}
N_{\text {э }}=0,5 \cdot 6 \cdot 365=1095 \text { кВт.год, } \\
C e=0,618 \cdot 1095=676,7 \text { грн }
\end{gathered}
$$

Виходячи 3 даних таблиці 6 , вартість активатора реагентів становить 6300 грн, з урахуванням цього річний економічний ефект від впровадження запропонованої технології з використанням активованого розчину коагулянту сульфату алюмінію становитиме:

$$
E=274000-219000-676.6-6300=48023 \text { грн. }
$$

Таким чином, 3 економічної точки зору впровадження в схему очищення дренажних вод полігонів ТПВ, технології з використанням активованого розчину коагулянту сульфату алюмінію $\epsilon$ технологічно виправданим та економічно доцільним. 


\section{ВИСНОВКИ}

Таким чином, під час вибору методу очищення дренажних стічних вод необхідно враховувати багатокомпонентність і коливання якісного складу дренажних вод полігонів ТПВ.

Використана методика проведення досліджень дозволила в лабораторних умовах і на пілотній установці обгрунтувати можливість інтенсифікації процесів коагуляції за рахунок застосування активованого розчину коагулянту.

Встановлено, що застосування активованого розчину коагулянту сульфату алюмінію дозволяє знизити розрахункову дозу коагулянту, в порівнянні зі звичайним розчином коагулянту, в середньому на 25-30\% без погіршення якості очищених стічних вод полігонів, що підтверджує доцільність використання активованих розчинів реагентів під час очищення стічних вод полігонів ТПВ.

Методом повного факторного експерименту отримані математичні залежності для прогнозування ефекту очищення дренажних вод iз використанням активованого розчину коагулянту - сульфату алюмінію за різних якісних показників вихідної води та дозі коагулянту.

Порівняння та аналіз отриманих даних дозволили зробити висновок про можливість застосування отриманих математичних залежностей для практичних цілей та обгрунтування використання активованого розчину коагулянту сульфату алюмінію для інтенсифікації процесу очищення дренажних вод.

Встановлено, що в разі використання активованого розчину коагулянту середня швидкість ущільнення контактного середовища вище, ніж у разі застосування звичайного розчину коагулянту, відбувається зміцнення пластівців осаду, покращення його седиментаційних властивостей, що дозволить збільшити сили зчеплення часток контактного середовища в середньому на 15-30\%, тим самим покращити ефективність біологічного очищення на біодискових фільтрах та підвищити ефект реагентного очищення загалом.

\section{АНОТАЦІЯ}

Розглянута проблема утворення фільтраційних вод під час експлуатації полігонів ТПВ на різних етапах. Проаналізовані зміни якісного складу дренажних вод на стадіях ацетогенезу та метаногенезу. Наведені граничні умови використання хімічних, фізичних, біологічних методів та їхні комбінації, представлені рекомендації щодо їх використання.

На підставі проведеного аналізу та виконаних досліджень запропонована ефективна технологія очищення за рахунок комбінації фізико-хімічного та біологічного методів. 
У роботі наведені результати дослідження ефективності очищення фільтрату полігонів твердих побутових відходів з використанням біодіскових фільтрів і активованого розчину коагулянту сульфату алюмінію.

Отримана емпірична залежність прогнозування якості очищення дренажних стічних вод за основними якісними показниками, яка може бути використана в технологічних розрахунках. Доведена технологічна та економічна доцільність запропонованої технології очищення.

\section{ЛITЕРАТУРА}

1. Кашковський B.I., Кухар В.П. Способи знешкодження високотоксичних стоків звалищ твердих побутових відходів. Наука та іновачіï. 2005. № 6. Т. 1 С. 107-116.

2. Ресурсосберегающие технологии очистки сточных вод : монография / С.С. Душкин и др. ; Харьк. нац. акад. городского хоз-ва. Харьков : ХНАГХ, 2011. $168 \mathrm{c.}$

3. Baig S., Coulomb I., Courant P. Treatment of landfill leachates : Lapeyrouse and Satrod case studies. Ozone science and engineering. 1999. 21. P. 1-22.

4. Safaa. M. Raghab, Ahmed M Abd EI Meguid, Hala A Hegazi. Treatment of leachate from municipal solid waste landfill. HBRC Journal. 2013. № 9. P. 187-192.

5. Welander U., Henrysson T. Nitrification of landfill Leachate Using Suspended-Carrier Biofilm Technology. Water Research. 1997. № 31 (9). P. 2351-2355.

6. Пат. № 45190 Україна, МПК ${ }^{51}$ (2009) CO2F 1/48 Спосіб очищення стічних вод полігонів твердих побутових відходів / Душкін С.С. та ін. Заявник та правовласник ХНАМГ. № 45190 ; заявл. 09.06.2009 р. ; опубл. 26.10.2009 р., Бюл. № 20.

7. Дегтяр М.В. Інтенсифікація процесів очищення висококонцентрованих стічних вод. Вісник Національного університету водного господарства та природокористування : зб. наукових праць. Рівне : НУВГП, 2015. Вип. 1 (69). С. 111-116.

8. Джонсон Н., Лион Ф. Статистика и планирование эксперимента в технике и науке. Москва : Мир, 1988. 520 с.

\section{Information about the author:} Dehtiar M. V.,

Candidate of Technical Sciences, Associate Professor, O. M. Beketov National University of Urban Economy in Kharkiv 17, Marshall Bazhanov, str., Kharkiv, 61002, Ukraine 